ISSN 1678-3921

Journal homepage: www.embrapa.br/pab

For manuscript submission and journal contents, access: www.scielo.br/pab

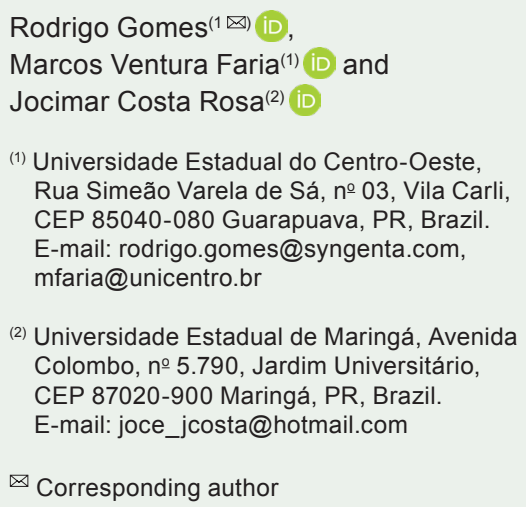

(2) Universidade Estadual de Maringá, Avenida Colombo, no 5.790, Jardim Universitário, CEP 87020-900 Maringá, PR, Brazil. E-mail: joce_jcosta@hotmail.com

$\bowtie$ Corresponding author

Received

February 26, 2020

Accepted

September 10, 2020

How to cite

GOMES, R.; FARIA, M.V.; ROSA, J.C. Selection of corn inbred lines, testers, and hybrids adapted to second-crop environments. Pesquisa Agropecuária Brasileira, v. 55 e01832, 2020. DOI: https://doi.org/10.1590/ S1678-3921.pab2020.v55.01832.

\section{Selection of corn inbred lines, testers, and hybrids adapted to second-crop environments}

\begin{abstract}
The objective of this work was to evaluate the yield performance, adaptability, and stability of corn (Zea mays) topcross hybrids in nine environments in Brazil, in order to select inbred lines, testers, and promising hybrid combinations for these environments in the second crop season. The trials were carried out during the second crop season of 2017, in six sites in the state of Parana and three in the state of Mato Grosso do Sul, Brazil. Sixty-six single-cross hybrids, made up of 33 inbred lines crossed with two testers, were evaluated. The stability of the genotypes was assessed by the Schmidt \& Cruz method and by the additive main effects and multiplicative interaction (AMMI) methodology. In addition, the genetic parameters and the general combining ability of the testers were estimated. Tester 2 is the most adapted to discriminate inbred lines in the second-crop environments. Inbred lines 12, 21, 23, and 32 are recommended for obtaining hybrids to be cultivated in the second crop season due to their good adaptability and stability and high yield in the crosses in which they participated. The HS123, HS223, and HS232 hybrids present the best performance and are the most recommended for the second-crop environments.
\end{abstract}

Index terms: Zea mays, adaptability and stability, AMMI methodology.

\section{Seleção de linhagens, testadores e híbridos de milho adaptados a ambientes de segunda safra}

Resumo - O objetivo deste trabalho foi avaliar o desempenho produtivo, a adaptabilidade e a estabilidade de híbridos topcross de milho (Zea mays) em nove ambientes no Brasil, para selecionar linhagens, testadores e combinações híbridas promissoras para esses ambientes na segunda safra. Os experimentos foram instalados durante a segunda safra de 2017, em seis localidades no estado do Paraná e três no estado de Mato Grosso do Sul. Foram avaliados 66 híbridos simples, compostos por 33 linhagens cruzadas com 2 testadores. A estabilidade dos genótipos foi avaliada pelo método de Schmidt \& Cruz e pela metodologia "additive main effects and multiplicative interaction" (AMMI). Também foram estimados os parâmetros genéticos e a capacidade geral de combinação dos testadores. O testador 2 é o mais adaptado para discriminar as linhagens em ambientes de segunda safra. As linhagens 12, 21, 23 e 32 são recomendadas para a obtenção de híbridos para cultivo na segunda safra, devido à sua boa adaptabilidade e estabilidade e ao seu alto rendimento nos cruzamentos em que participaram. Os híbridos HS123, HS223 e HS232 apresentam o melhor desempenho e são os mais recomendados para ambientes de segunda safra.

Termos para indexação: Zea mays, adaptabilidade e estabilidade, metodologia AMMI. 


\section{Introduction}

Currently in Brazil, the second corn (Zea mays L.) crop season covers a larger cultivation area and generates a greater production volume than the first one (Dorigatti, 2020). However, the environmental conditions of the second crop are a challenge to continue expanding production, since recent-past investments and research were focused mainly on the first season (Van Eeuwijk et al., 2016; Faria et al., 2017).

According to Roozeboom etal.(2008), environmental conditions can highly compromise the performance of the corn crop, directly affecting grain yield. Therefore, due to the great soil and climatic variability of the environments in the second crop season (Andrea et al., 2018), it is important to select corn genotypes specific for cultivation during this time of the year.

For this reason, breeding programs, which previously focused on the summer crop, have started to prioritize the development of corn hybrids that are more adapted to and productive in second-crop environments, especially due to the few known works on hybrids to be cultivated specifically in the second crop season (Figueiredo et al., 2015; Gabriel et al., 2018).

Obtaining corn hybrids involves several steps that demand time and resources (Ramalho et al., 2012). In this process, the use of a topcross methodology is an important strategy to evaluate the genetic merit of inbred lines, allowing to assess their ability in generating valuable hybrids through the selection of promising hybrids at an early stage and that are adapted to the targeted environments (Oyekunle et al., 2017; Possatto Junior et al., 2017). To assess topcrosses, it is also fundamental to choose suitable testers, efficient in classifying correctly the genetic merit of the inbred lines (Costa et al., 2010; Figueiredo et al., 2018). However, up to date, few studies have used testers to evaluate the merit of corn inbred lines adapted to second-crop environments (Clovis et al., 2015; Bolson et al, 2016).

For consistent results in the assessment of topcrosses, the genotype $\mathrm{x}$ environment (GxE) interaction should also be taken into account (Figueiredo et al., 2018). In the case of the present work, considering that the inbred lines were developed under summer conditions and evaluated in second-crop environments, the analysis of adaptability and stability and the estimates of the genetic parameters were key tools in the development of high-performance genotypes adapted to the environments of interest (Figueiredo et al., 2015; Di Matteo et al., 2016).

Regarding the adaptability and stability of corn topcrosses, the analysis of the additive main effects and multiplicative interaction (AMMI) can provide consistent results in the identification of promising crosses adapted to environments in the second crop season (Duarte \& Vencovsky, 1999; Bolson et al., 2016). An advantage is the joint study of additive and multiplicative effects, allowing a more efficient and easier selection by plotting the obtained data in easily interpreted graphs (Das et al., 2019). When that methodology is applied to topcrosses, it is possible to select specific hybrids, inbred lines, and testers adapted to certain environments (Duarte \& Vencovsky, 1999; Silva et al., 2017).

The objective of this work was to evaluate the yield performance, adaptability, and stability of corn topcross hybrids in nine environments in Brazil, in order to select inbred lines, testers, and promising hybrid combinations for these environments in the second crop season.

\section{Materials and Methods}

The used genetic material is composed of 66 singlecross corn hybrids, obtained from controlled crosses of 33 inbred lines with two testers. The inbred lines are from different heterotic groups, developed in summer conditions by the corn breeding program of Nidera Sementes and selected at least once in secondcrop environments. The testers, also from different heterotic groups, are both elite lines, but one was selected in a summer environment (tester 1) and the other in a second-crop environment (tester 2).

The 66 single-cross hybrids were evaluated during the second crop season of 2017, in six sites in the state of Paraná (Toledo, Palotina, Assis Chateaubriand, Campo Mourão, Sertanópolis, and São Jorge do Ivaí) and in three sites in the state of Mato Grosso do Sul (Caarapó, Itaporã, and Douradina), corresponding to nine environments (Table 1).

The trials were carried out in a complete block design, with randomized treatments and two replicates. It was decided to use only two replicates due to the limited number of seeds obtained in the different crossings; however, it was still possible to carry out statistical analyzes of adaptability and stability as

Pesq. agropec. bras., Brasília, v.55, e01832, 2020

DOI: 10.1590/S1678-3921.pab2020.v55.01832 
done by Faria et al. (2017) and Oliveira et al. (2017). In each site, the useful area of each plot was made up of four 5-m rows, with a spacing of $0.55 \mathrm{~m}$ between lines and 18 plants per row, equivalent to a population density of 65.500 plants per hectare. The control of pests and diseases was carried out when necessary, according to the recommendations for the cultivation of corn (Fornasieri Filho, 2007). There was no need for irrigation, since the precipitation index was sufficient to meet crop requirements in all experiments. Grain yield was considered the weight of the grains of all the ears of each plot, corrected to $13 \%$ moisture.

The stability of the genotypes was evaluated using the Schmildt \& Cruz (2005) method, according to the following models: $I_{i}=\bar{Y}_{i}-Z(1-\alpha)\left(\sigma_{i} / V_{n}\right)$ for the general environment, $I_{i d}=\bar{Y}_{i d}-Z(1-\alpha)\left(\sigma_{i d} / \sqrt{d}\right)$ for unfavorable environments, and $\mathrm{I}_{\mathrm{if}}=\overline{\mathrm{Y}}_{\text {if }}-\mathrm{Z}(1-\alpha)$ $\left(\sigma_{\mathrm{if}} / V_{\mathrm{f}}\right)$ for favorable environments, where $\mathrm{I}_{\mathrm{i}}$ is the stability confidence index; $\bar{Y}_{i}$ is the mean of each genotype; $\sigma_{i}$ is the standard deviation; $Z(1-\alpha)$ is the value in the standard normal distribution, in which the function of accumulated distribution reaches value $(1-\alpha)-95 \% ; n$ is the total number of environments; $d$ is the number of unfavorable environments; and $f$ is the number of favorable environments.

Stability and adaptability were also evaluated using the AMMI methodology (Zobel et al., 1988), through the model: $Y_{i j}=\mu+g_{i}+a_{j}+\Sigma \lambda_{k} \gamma_{i k} \alpha_{j k}+\rho_{i j}+\bar{e}_{i j}$, where $\mathrm{Y}_{\mathrm{ij}}$ is the mean response of genotype $\mathrm{i}(\mathrm{i}=1,2, \ldots, 66)$, in environment $\mathrm{j}(\mathrm{j}=1,2, \ldots, 9) ; \mu$ is the general mean of the experiment; $g_{i}$ is the fixed effect of genotype $i ; a_{j}$ is the random effect of environment j; $\Sigma \lambda_{\mathrm{k}}$ is the value of the original interaction matrix, denoted by the GxE interaction; $\gamma_{\mathrm{ik}}$ is the element corresponding to the ith genotype in the kth vector of the GxE matrix; $\alpha_{j k}$ is the element corresponding to the jth environment in the kth singular vector line of the GxE matrix; $\rho_{\mathrm{ij}}$ is the residue of the GxE interaction; and $\overline{\mathrm{e}}_{\mathrm{ij}}$ is the experimental mean error associated with the ith genotype in the jth environment, assumed as independent.

The GxE matrix is the interaction matrix between genotypes and environments, i.e., the residue matrix of main effects. In it, each element $(\mathrm{GE})_{\mathrm{ij}}$ of the GxE interaction is given by: $(\mathrm{GE})_{\mathrm{ij}}=\mathrm{Y}_{\mathrm{ij}}-\overline{\mathrm{Y}}_{\mathrm{i}}-\overline{\mathrm{Y}}_{\mathrm{j}}+$ $\bar{Y}$, where $Y_{i j}$ is the mean of the replicates of genotype $i$ in environment $j, \bar{Y} i$ is the mean of genotype $i, \bar{Y} j$ is the mean of environment $j$, and $\bar{Y}$ is the general mean of the experiment. Genetic variance $\left(\sigma^{2} G\right)$ was estimated by: $\sigma^{2} \mathrm{G}=(\mathrm{MSG}-\mathrm{MSE}) / \mathrm{r}$, where MSG is the mean square of the genotypes, MSE is the mean squared error, and $r$ is the number of replicates. The error variance $\left(\sigma^{2}\right)$ was obtained by $\sigma^{2}=\mathrm{MSE} / \mathrm{r}$, where MSE is the mean squared error and $r$ is the number of replicates. Broad-sense heritability $\left(\mathrm{h}_{\mathrm{a}}{ }^{2}\right)$ was estimated by $h_{a}{ }^{2}=\sigma^{2} G /\left(\sigma^{2} G+\sigma^{2}\right)$, where $\sigma^{2} G$ is the component of genetic variance and $\sigma^{2}$ is the component of residual variance. The coefficient of genetic variation $(\mathrm{CVg})$ was determined by $\mathrm{CVg}=\left[\left(\sigma_{\mathrm{G}}^{2}\right)^{1 / 2} / \mathrm{m}\right]$ x 100 , where $\sigma_{\mathrm{G}}^{2}$ is the component of genetic variance and $\mathrm{m}$ is the estimated average.

The partial diallel analysis between testers and inbred lines was carried out considering the genitors and the $F_{1}$ hybrid combinations, according to the statistical model proposed by Geraldi \& Miranda Filho (1988): $\mathrm{Y}_{\mathrm{ijk}}=\mu+\mathrm{G}_{\mathrm{i}}+\mathrm{G}_{\mathrm{j}}+\mathrm{S}_{\mathrm{ij}}+\mathrm{A}_{\mathrm{k}}+\mathrm{GA}_{\mathrm{ik}}+\mathrm{GA}_{\mathrm{jk}}+$ $\mathrm{SA}_{\mathrm{ijk}}+\mathrm{E}_{\mathrm{ijk}}$, where $\mathrm{Y}_{\mathrm{ijk}}$ is the average value observed

Table 1. Sites and geographic coordinates of the nine evaluated environments and respective corn (Zea mays) sowing dates, in the states of Paraná (PR) and Mato Grosso do Sul (MS), Brazil ${ }^{(1)}$.

\begin{tabular}{|c|c|c|c|c|c|c|c|}
\hline Environment & Site & Latitude & Longitude & $\begin{array}{l}\text { Altitude } \\
\text { (m) }\end{array}$ & $\begin{array}{c}\text { Temperature } \\
\left({ }^{\circ} \mathrm{C}\right)\end{array}$ & $\begin{array}{c}\text { Rainfall } \\
(\mathrm{mm})\end{array}$ & $\begin{array}{c}\text { Sowing } \\
\text { date }\end{array}$ \\
\hline E1-PR & Toledo & -24.6785 & -53.7693 & 549 & 19.4 & 1,483 & $2 / 3 / 2017$ \\
\hline E2-PR & Palotina & -24.3437 & -53.8269 & 370 & 20.8 & 1,508 & $2 / 5 / 2017$ \\
\hline E3-PR & Assis Chateaubriand & -24.5017 & -53.7214 & 446 & 20.3 & 1,581 & $2 / 6 / 2017$ \\
\hline E4-PR & Campo Mourão & -24.0332 & -52.4246 & 613 & 19.9 & 1,570 & $2 / 8 / 2017$ \\
\hline E5-PR & Sertanópolis & -23.039 & -51.0026 & 356 & 22.5 & 1,635 & $2 / 10 / 2017$ \\
\hline E6-PR & São Jorge do Ivaí & -23.4206 & -52.2879 & 432 & 21.2 & 1,610 & $2 / 13 / 2017$ \\
\hline E7-MS & Caarapó & -22.6963 & -54.8748 & 592 & 21.7 & 1,594 & $2 / 16 / 2017$ \\
\hline E8-MS & Itaporã & -22.0534 & -54.5213 & 297 & 23.4 & 1,621 & $2 / 20 / 2017$ \\
\hline E9-MS & Douradina & -22.0456 & -54.3622 & 337 & 22.7 & 1,428 & $2 / 23 / 2017$ \\
\hline
\end{tabular}

${ }^{(1)}$ Temperature and rainfall values refer to the annual average. Source: Inmet (2020). 
in the hybrid combination between inbred line $\mathrm{i}$ and tester $\mathrm{j}, \mu$ is the overall average of the experiment, $G_{i}$ is the effect of the general combining ability (GCA) of inbred line $\mathrm{i}(\mathrm{i}=1,2, \ldots 33), \mathrm{G}_{\mathrm{j}}$ is the effect of the GCA of tester $\mathrm{j}(\mathrm{j}=1,2), \mathrm{S}_{\mathrm{ij}}$ is the effect of the specific combining ability (SCA) between inbred line $\mathrm{i}$ and tester $\mathrm{j}, \mathrm{A}_{\mathrm{k}}$ is the effect of environment $\mathrm{k}$ $(\mathrm{k}=1,2, \ldots 9), \mathrm{GA}_{\mathrm{ik}}$ is the effect of the interaction between the GCA of inbred line $\mathrm{i}$ and environment $\mathrm{k}$, $\mathrm{GA}_{\mathrm{jk}}$ is the effect of the interaction between the GCA of tester $\mathrm{j}$ and environment $\mathrm{k}, \mathrm{SA}_{\mathrm{ijk}}$ is the effect of the interaction between the SCA of inbred line $i$ and tester $\mathrm{j}$ in environment $\mathrm{k}$, and $\mathrm{E}_{\mathrm{ijk}}$ is the random experimental error associated with observation $\mathrm{Y}_{\mathrm{ij}}$.

The GCA $\left(g_{i}\right.$ and $\left.g_{j}\right)$ and SCA $\left(s_{i j}\right)$ estimates were calculated as follows: $g_{i}=Y_{i}-\mu, g_{j}=Y_{j}-\mu$, and $s_{i j}=$ Yij - $\left(\mu+g_{i}+g_{j}\right)$, where $Y_{i}$ is the overall average of the hybrid combinations of inbred line $i$ and $Y_{j}$ is the overall average of the hybrid combinations of tester $j$.

The analyzes were performed using the Genes (Cruz, 2013) and R (R Core Team, 2015) statistical software.

\section{Results and Discussion}

The GxE interaction was significant $(\mathrm{p} \leq 0.05)$, indicating differences in genotype yield due to environmental variations. The influence of environmental conditions in the second crop season justifies the need for studies on the adaptability, stability, and performance of genotypes for breeding purposes (Di Matteo et al., 2016; Possatto Junior et al.,
2017). As emphasized by Gauch Jr. (2013), the best genotypes should ideally be selected considering yield estimates.

Based on the stability analysis of Schmildt et al. (2005), environments 1, 2, 6, 8, and 9 were classified as favorable (Table 2), with a positive environmental index, characterizing environments that allow the expression of the productive potential of the genotypes and, consequently, the selection of the most adapted hybrids. Environments 3, 4, 5, and 7 had negative environmental indexes and were classified as unfavorable, allowing to assess the stability of genotypes in adverse conditions (Roozeboom et al., 2008).

Regarding the performance of the testers in each environment, tester 2, which is an elite inbred line selected in second-crop conditions, provided hybrids with higher mean grain yields in most of the unfavorable (3, 4, and 5) and favorable (6, 8, and 9) environments, which suggests that this tester tends to be the most stable and adapted to the respective environments. The general index mean was 93.68 for the hybrids with tester 1 (Table 3) and 91.93 for the hybrids with tester 2 (Table 4). These values are appropriate considering the positive response of the genotypes under the conditions of the second crop season in the evaluated environments, allowing the selection of desirable extremes (Ramalho et al., 2012; Di Matteo et al., 2016).

Of the topcross hybrids that had higher indexes of stability, HS222, HS232, and HS233 stood out, showing their greater potential for selection, besides confirming

Table 2. Ranking of the nine environments, based on the analysis of stability of Schmildt \& Cruz (2005), used for the evaluation of 66 corn (Zea mays) genotypes during the second crop season in the states of Paraná and Mato Grosso do Sul, Brazil.

\begin{tabular}{lccccc}
\hline Environment ${ }^{(1)}$ & $\begin{array}{c}\text { Average grain yield } \\
\left(\mathrm{kg} \mathrm{ha}^{-1}\right)\end{array}$ & Index & Class & $\begin{array}{c}\text { Average of tester 1 } \\
\left(\mathrm{kg} \mathrm{ha}^{-1}\right)\end{array}$ & $\begin{array}{c}\text { Average of tester 2 } \\
\left(\mathrm{kg} \mathrm{ha}^{-1}\right)\end{array}$ \\
\hline 1 & $8,953.2$ & 0.3004 & Favorable & 8,830 & 9,075 \\
2 & $9,618.8$ & 0.9660 & Favorable & 9,428 & 7,735 \\
3 & $8,007.0$ & -0.6457 & Unfavorable & 6,721 & 8,807 \\
4 & -1.4692 & Unfavorable & 7,999 & 7,640 \\
5 & $7,183.5$ & -0.5943 & Unfavorable & 10,140 & 8,112 \\
6 & $8,058.3$ & 0.9464 & Favorable & 8,633 & 9,525 \\
7 & $9,599.1$ & -1.5074 & Unfavorable & 9,473 & 8,365 \\
8 & $8,502.0$ & 0.2354 & Favorable & 9,446 & 8,297 \\
\hline
\end{tabular}

(1)In the state of Paraná: 1, Toledo; 2, Palotina; 3, Assis Chateaubriand; 4, Campo Mourão; 5, Sertanópolis; and 6, São Jorge do Ivaí. In the state of Mato Grosso do Sul: 7, Caarapó; 8, Itaporã; and 9, Douradina. 
the good performance of tester 2, which was the common parent of these hybrids (Tables 3 and 4).

For the unfavorable environments, the mean grain yield of all hybrids was $7,938 \mathrm{~kg} \mathrm{ha}^{-1}$. In these environments, the HS102 (Table 3) and HS222 (Table 4) hybrids had high indexes of stability, but a low mean grain yield. Since isolated values of stability do not reflect the real genetic value of the genotypes, it is necessary to combine good stability and high mean grain yields (Roozeboom et al., 2008; Figueiredo et al., 2015).

The mean grain yield of the topcross hybrids in the favorable environments was $9,224 \mathrm{~kg} \mathrm{ha}^{-1}$. According to the analysis of stability, hybrids HS123, HS222, HS232, and HS233 had good stability indexes and high mean grain yields, in both favorable and unfavorable environments, which makes them promising considering the assessed environments (Tables 3 and 4).

Table 3. Indexes of general stability and of unfavorable and favorable environments for the 33 corn (Zea mays) hybrid topcrosses with tester 1, evaluated in nine environments ${ }^{(1)}$ in the second crop season, in the states of Paraná and Mato Grosso do Sul, Brazil.

\begin{tabular}{|c|c|c|c|c|c|c|c|c|}
\hline Hybrid & Tester & $\begin{array}{l}\text { Inbred } \\
\text { line }\end{array}$ & $\begin{array}{l}\text { General } \\
\text { index }\end{array}$ & $\begin{array}{c}\text { General average } \\
\left(\mathrm{kg} \mathrm{ha}^{-1}\right)\end{array}$ & $\begin{array}{c}\text { Index of } \\
\text { unfavorable } \\
\text { environments }\end{array}$ & $\begin{array}{l}\text { Average of unfavo- } \\
\text { rable environments } \\
\left(\mathrm{kg} \mathrm{ha}^{-1}\right)\end{array}$ & $\begin{array}{c}\text { Index of favorable } \\
\text { environments }\end{array}$ & $\begin{array}{l}\text { Average of favo- } \\
\text { rable environments } \\
\left(\mathrm{kg} \mathrm{ha}^{-1}\right)\end{array}$ \\
\hline HS101 & 1 & 1 & 96.26 & 8,991 & 93.69 & 8,283 & 97.83 & 9,538 \\
\hline HS102 & 1 & 2 & 99.66 & 9,253 & 110.21 & 9,223 & 93.60 & 9,280 \\
\hline HS103 & 1 & 3 & 97.32 & 8,686 & 96.27 & 7,960 & 97.86 & 9,270 \\
\hline HS104 & 1 & 4 & 97.07 & 8,746 & 98.47 & 7,863 & 97.23 & 9,454 \\
\hline HS105 & 1 & 5 & 83.10 & 7,828 & 82.03 & 7,293 & 83.43 & 8,262 \\
\hline HS106 & 1 & 6 & 96.34 & 8,978 & 90.75 & 7,920 & 100.95 & 9,828 \\
\hline HS107 & 1 & 7 & 90.97 & 8,558 & 87.50 & 7,893 & 93.64 & 9,094 \\
\hline HS108 & 1 & 8 & 98.73 & 8,843 & 98.14 & 7,885 & 100.21 & 9,614 \\
\hline HS109 & 1 & 9 & 94.82 & 8,941 & 89.07 & 7,905 & 99.23 & 9,774 \\
\hline HS110 & 1 & 10 & 92.43 & 8,758 & 83.99 & 7,608 & 100.64 & 9,682 \\
\hline HS111 & 1 & 11 & 91.70 & 8,505 & 86.21 & 7,295 & 97.63 & 9,476 \\
\hline HS 112 & 1 & 12 & 100.08 & 9,103 & 100.90 & 8,338 & 99.12 & 9,718 \\
\hline HS113 & 1 & 13 & 98.59 & 8,911 & 99.16 & 8,030 & 98.62 & 9,618 \\
\hline HS114 & 1 & 14 & 100.93 & 9,152 & 97.31 & 8,113 & 104.07 & 9,988 \\
\hline HS115 & 1 & 15 & 80.96 & 8,132 & 87.13 & 7,388 & 77.05 & 8,732 \\
\hline HS116 & 1 & 16 & 94.27 & 8,874 & 87.71 & 7,405 & 102.37 & 10,054 \\
\hline HS117 & 1 & 17 & 93.52 & 8,744 & 89.28 & 7,443 & 98.87 & 9,788 \\
\hline HS118 & 1 & 18 & 99.15 & 9,051 & 102.91 & 8,475 & 96.12 & 9,518 \\
\hline HS119 & 1 & 19 & 95.90 & 8,896 & 99.02 & 8,438 & 93.03 & 9,266 \\
\hline HS120 & 1 & 20 & 94.49 & 8,849 & 90.87 & 7,880 & 96.86 & 9,630 \\
\hline HS121 & 1 & 21 & 95.99 & 9,456 & 88.62 & 7,860 & 102.53 & 10,196 \\
\hline HS122 & 1 & 22 & 84.23 & 8,187 & 83.97 & 7,835 & 82.80 & 9,012 \\
\hline HS123 & 1 & 23 & 102.40 & 9,236 & 101.81 & 8,320 & 102.84 & 9,974 \\
\hline HS124 & 1 & 24 & 91.95 & 8,573 & 85.36 & 7,038 & 103.05 & 9,806 \\
\hline HS125 & 1 & 25 & 88.87 & 8,265 & 86.12 & 7,440 & 90.45 & 8,930 \\
\hline HS126 & 1 & 26 & 88.00 & 8,154 & 84.00 & 7,070 & 91.94 & 9,030 \\
\hline HS127 & 1 & 27 & 90.81 & 8,533 & 95.00 & 7,770 & 88.54 & 9,148 \\
\hline HS128 & 1 & 28 & 95.36 & 8,786 & 92.29 & 7,678 & 98.55 & 9,678 \\
\hline HS129 & 1 & 29 & 89.23 & 8,114 & 89.34 & 7,350 & 89.14 & 8,730 \\
\hline HS130 & 1 & 30 & 99.69 & 9,081 & 94.22 & 7,828 & 106.17 & 10,086 \\
\hline HS131 & 1 & 31 & 83.88 & 7,802 & 80.92 & 6,710 & 87.35 & 8,680 \\
\hline HS132 & 1 & 32 & 97.96 & 9,168 & 89.25 & 7,965 & 107.04 & 10,136 \\
\hline HS133 & 1 & 33 & 86.94 & 8,338 & 86.16 & 7,073 & 90.20 & 9,356 \\
\hline Mean & & & 93.68 & 8,712 & 91.75 & 7,775 & 96.03 & 9,465 \\
\hline
\end{tabular}

(1) In the state of Paraná: 1, Toledo; 2, Palotina; 3, Assis Chateaubriand; 4, Campo Mourão; 5, Sertanópolis; and 6, São Jorge do Ivaí. In the state of Mato Grosso do Sul: 7, Caarapó; 8, Itaporã; and 9, Douradina. 
The results obtained in the present work are in alignment with data from other authors that show topcross hybrids with high mean grain yields, and the analysis of the adaptability and stability of the topcrosses can be considered as an efficient method for the evaluation and selection of inbred lines and testers, as well as for the identification of hybrids with good performance (Pfann et al., 2009; Oliboni et al., 2013; Di Matteo et al., 2016; Silva et al., 2017).
The estimates of the variance components indicate that environments 3 and 4 provided the best conditions for expressing the grain yield of the topcross hybrids with tester 1 , with about $60 \%$ heritability. However, in environments 5 and 9, the genotypes responded with low values of genetic variance, and, consequently, low heritability, showing that the environment can influence the expression of variability, justifying the need for the selection of testers adapted to specific

Table 4. Indexes of general stability and of unfavorable and favorable environments for the 33 corn (Zea mays) hybrid topcrosses with tester 2, evaluated in nine environments ${ }^{(1)}$ in the second crop season, in the states of Paraná and Mato Grosso do Sul, Brazil.

\begin{tabular}{|c|c|c|c|c|c|c|c|c|}
\hline Hybrid & Tester & Inbred lines & $\begin{array}{c}\text { General } \\
\text { index }\end{array}$ & $\begin{array}{l}\text { General } \\
\text { average } \\
\left(\mathrm{kg} \mathrm{ha}^{-1}\right)\end{array}$ & $\begin{array}{c}\text { Index of } \\
\text { unfavorable } \\
\text { environments }\end{array}$ & $\begin{array}{c}\text { Average of unfavorable } \\
\text { environments } \\
\left(\mathrm{kg} \mathrm{ha}^{-1}\right)\end{array}$ & $\begin{array}{c}\text { Index of } \\
\text { favorable } \\
\text { environments }\end{array}$ & $\begin{array}{c}\text { Average of favorable } \\
\text { environments } \\
\left(\mathrm{kg} \mathrm{ha}^{-1}\right)\end{array}$ \\
\hline HS201 & 2 & 1 & 92.27 & 8,577 & 88.23 & 7,493 & 95.90 & 9,450 \\
\hline HS202 & 2 & 2 & 97.14 & 8,895 & 100.57 & 8,363 & 94.19 & 9,326 \\
\hline HS203 & 2 & 3 & 91.21 & 8,540 & 99.38 & 8,583 & 88.03 & 8,506 \\
\hline HS204 & 2 & 4 & 90.35 & 8,324 & 94.57 & 7,868 & 86.93 & 8,696 \\
\hline HS205 & 2 & 5 & 89.58 & 8,536 & 94.73 & 8,128 & 85.13 & 8,868 \\
\hline HS206 & 2 & 6 & 98.66 & 9,017 & 95.02 & 7,918 & 102.10 & 9,900 \\
\hline HS207 & 2 & 7 & 90.25 & 8,147 & 91.55 & 7,573 & 88.88 & 8,610 \\
\hline HS208 & 2 & 8 & 93.09 & 8,472 & 102.34 & 8,368 & 88.98 & 8,560 \\
\hline HS209 & 2 & 9 & 89.39 & 8,430 & 83.92 & 7,175 & 94.76 & 9,440 \\
\hline HS210 & 2 & 10 & 89.87 & 8,401 & 86.45 & 7,325 & 92.94 & 9,264 \\
\hline HS211 & 2 & 11 & 87.11 & 8,184 & 92.71 & 7,970 & 82.88 & 8,362 \\
\hline HS212 & 2 & 12 & 101.91 & 9,427 & 105.43 & 8,935 & 98.82 & 9,826 \\
\hline HS213 & 2 & 13 & 87.09 & 8,150 & 80.59 & 6,903 & 93.83 & 9,154 \\
\hline HS214 & 2 & 14 & 91.66 & 8,367 & 90.26 & 7,660 & 92.21 & 8,938 \\
\hline HS215 & 2 & 15 & 82.43 & 8,184 & 91.27 & 7,715 & 76.18 & 8,564 \\
\hline HS216 & 2 & 16 & 89.94 & 8,316 & 90.60 & 7,520 & 89.26 & 8,958 \\
\hline HS2 217 & 2 & 17 & 83.95 & 7,664 & 91.36 & 7,540 & 80.24 & 7,770 \\
\hline HS2 18 & 2 & 18 & 97.58 & 9,088 & 104.64 & 8,690 & 92.49 & 9,412 \\
\hline HS219 & 2 & 19 & 84.45 & 7,860 & 83.81 & 7,318 & 84.40 & 8,298 \\
\hline HS220 & 2 & 20 & 93.78 & 8,613 & 98.57 & 8,218 & 90.11 & 8,936 \\
\hline HS221 & 2 & 21 & 99.44 & 9,272 & 107.36 & 8,988 & 93.88 & 9,504 \\
\hline HS222 & 2 & 22 & 101.93 & 8,445 & 105.65 & 9,465 & 100.70 & 9,792 \\
\hline HS223 & 2 & 23 & 92.61 & 9,694 & 95.55 & 7,868 & 90.18 & 9,000 \\
\hline HS224 & 2 & 24 & 38.03 & 8,258 & 95.65 & 7,945 & 6.800 & 5,404 \\
\hline HS225 & 2 & 25 & 97.52 & 8,954 & 99.68 & 8,560 & 96.83 & 9,272 \\
\hline HS226 & 2 & 26 & 95.57 & 8,908 & 102.74 & 8,440 & 90.65 & 9,288 \\
\hline HS227 & 2 & 27 & 100.77 & 9,101 & 102.98 & 8,510 & 98.75 & 9,578 \\
\hline HS228 & 2 & 28 & 91.44 & 8,344 & 97.41 & 8,133 & 88.13 & 8,520 \\
\hline HS229 & 2 & 29 & 90.42 & 8,203 & 97.08 & 8,030 & 87.31 & 8,344 \\
\hline HS230 & 2 & 30 & 98.26 & 8,912 & 97.65 & 8,223 & 98.32 & 9,470 \\
\hline HS231 & 2 & 31 & 97.44 & 8,912 & 97.74 & 8,273 & 96.61 & 9,428 \\
\hline HS232 & 2 & 32 & 103.48 & 9,404 & 105.39 & 8,765 & 101.51 & 9,916 \\
\hline HS233 & 2 & 33 & 105.18 & 9,566 & 104.17 & 9,265 & 105.68 & 10,132 \\
\hline Mean & & & 91.93 & 8,641 & 96.21 & 8,128 & 89.50 & 8,984 \\
\hline
\end{tabular}

(1)In the state of Paraná: 1, Toledo; 2, Palotina; 3, Assis Chateaubriand; 4, Campo Mourão; 5, Sertanópolis; and 6, São Jorge do Ivaí. In the state of Mato Grosso do Sul: 7, Caarapó; 8, Itaporã; and 9, Douradina. 
conditions, in this case, to second-crop environments (Table 5).

Considering the components of variance and genetic parameters, hybrids with tester 2 , in general, were less affected by the environments regarding grain yield. The mean heritability values were $52.95 \%$ in the nine environments, while the mean heritability of the grain yield of the hybrids with tester 1 was $37.85 \%$ (Table 5), indicating that tester 2 is the best for discriminating the inbred lines in the environments where the respective hybrids were evaluated and is also the most suitable for use in the second crop (Clovis et al., 2015; Oyekunle et al., 2017).

The heritability of the grain yield of the hybrids with tester 2 was above $50 \%$ in environments $2,3,6,7,8$, and 9, with emphasis on environment 9, where heritability was $90.27 \%$. As also observed for the hybrids with tester 1, the genotypes suffered a greater interference in environment 5 , with a heritability of only $25 \%$ (Table 5). This discrepancy in the heritability values can be attributed to the multiplicative effects of the environments, detected just by the AMMI analysis and not by the analysis of genetic components, justifying the use of AMMI to identify both effects, allowing a greater accuracy in the selection of adapted inbred lines, hybrids, and testers (Duarte \& Vencovsky, 1999; Silva et al., 2017).

The significance of the GCA interaction of testers $x$ environments showed a distinct performance among testers in the contribution to hybrid grain yield in the environments they were evaluated. As the environments are very distinct, the occurrence of interactions was expected and must be considered in the choice of testers (Vencovsky \& Barriga, 1992). Tester 1 contributes positively to hybrid performance in environments 6, 7, and 9, while tester 2 contributes positively in environments $1,2,3,4,5$, and 8 (Figure 1).

The positive contribution of each tester was also related to the sites where the means of the respective topcross hybrids stood out. This way, it is possible to identify the tester with the highest GCA for each environment (Bolson et al., 2016). In general, tester 2 developed in conditions where the second crop presented the best performance considering the contribution of the GCA (Figure 1).

The GxE interaction was significant (Table 6). However, even when significant, this interaction cannot always point differences in the performance of the genotypes because the data may not be adjusted to the statistical model employed. It is, therefore, necessary

Table 5. Estimates of the components of variance and genetic parameters of the individual analyses of the grain yield of 66 corn (Zea mays) hybrids from crosses of 33 inbred lines with testers 1 and 2, evaluated in nine environments in the second crop season, in the states of Paraná and Mato Grosso do Sul, Brazil.

\begin{tabular}{|c|c|c|c|c|c|c|c|c|c|}
\hline \multirow[t]{2}{*}{ Parameter $^{(1)}$} & \multicolumn{9}{|c|}{ Environment $^{(2)}$} \\
\hline & 1 & 2 & 3 & 4 & 5 & 6 & 7 & 8 & 9 \\
\hline & \multicolumn{9}{|c|}{ Tester 1} \\
\hline$\sigma_{F}^{2}$ & 0.8359 & 13.76 & 0.8965 & 11.251 & 0.6087 & 11.087 & 11.205 & 16.21 & 0.9977 \\
\hline$\sigma_{G}^{2}$ & 0.3026 & 0.6287 & 0.5549 & 0.6703 & 0.1054 & 0.4582 & 0.4978 & 0.5051 & 0.0306 \\
\hline$\sigma_{\mathrm{E}}^{2}$ & 0.5332 & 0.7473 & 0.3415 & 0.4547 & 0.5033 & 0.6504 & 0.6227 & 11.159 & 0.967 \\
\hline$h^{2}(\%)$ & 36.2 & 45.68 & 61.9 & 59.57 & 17.32 & 41.33 & 44.42 & 31.16 & 3.07 \\
\hline CV (\%) & 11.48 & 12.89 & 10.39 & 13.85 & 14.67 & 11.19 & 12.89 & 15.72 & 14.65 \\
\hline \multirow[t]{2}{*}{$\mathrm{CVg}$} & 6.11 & 8.35 & 9.36 & 11.89 & 6.11 & 6.64 & 8.15 & 7.48 & 1.84 \\
\hline & \multicolumn{9}{|c|}{ Tester 2} \\
\hline$\sigma_{F}^{2}$ & 0.9842 & 14.924 & 0.7466 & 0.8515 & 0.9186 & 105.057 & 0.9751 & 17.508 & 0.8741 \\
\hline$\sigma_{G}^{2}$ & 0.4866 & 0.8198 & 0.3928 & 0.3065 & 0.2316 & 94.84 & 0.526 & 10.502 & 0.4737 \\
\hline$\sigma_{\mathrm{A}}^{2}$ & 0.4975 & 0.6725 & 0.3537 & 0.5449 & 0.6869 & 10.217 & 0.449 & 0.7005 & 0.4003 \\
\hline $\mathrm{h}^{2}(\%)$ & 49.44 & 54.93 & 52.62 & 36 & 25.22 & 90.27 & 53.94 & 59.98 & 54.2 \\
\hline CV (\%) & 10.83 & 11.81 & 9.97 & 13.59 & 14.5 & 15.46 & 11.25 & 13.95 & 10.14 \\
\hline CVg & 7.58 & 9.22 & 7.43 & 7.2 & 5.95 & 33.31 & 8.61 & 12.08 & 7.8 \\
\hline
\end{tabular}

${ }^{(1)} \sigma_{\mathrm{F}}^{2}$, phenotypic variance; $\sigma_{\mathrm{G}}^{2}$, genetic variance; $\sigma_{\mathrm{E}}^{2}$, environmental variance; $\mathrm{h}^{2}$, heritability; $\mathrm{CV}$, coefficient of variation; CVg, coefficient of genetic variation; and $\sigma_{\mathrm{A}}^{2}$, additive variance. ${ }^{(2)}$ In the state of Paraná: 1, Toledo; 2, Palotina; 3, Assis Chateaubriand; 4, Campo Mourão; 5, Sertanópolis; and 6, São Jorge do Ivaí. In the state of Mato Grosso do Sul: 7, Caarapó; 8, Itaporã; and 9, Douradina. 
to associate the additive model to the multiplicative one, evaluating the actual effects of the interaction (Ramalho et al., 2012; Mohamed, 2013).

The results of the joint analysis of variance showed a significant effect of genotypes, environments, and the

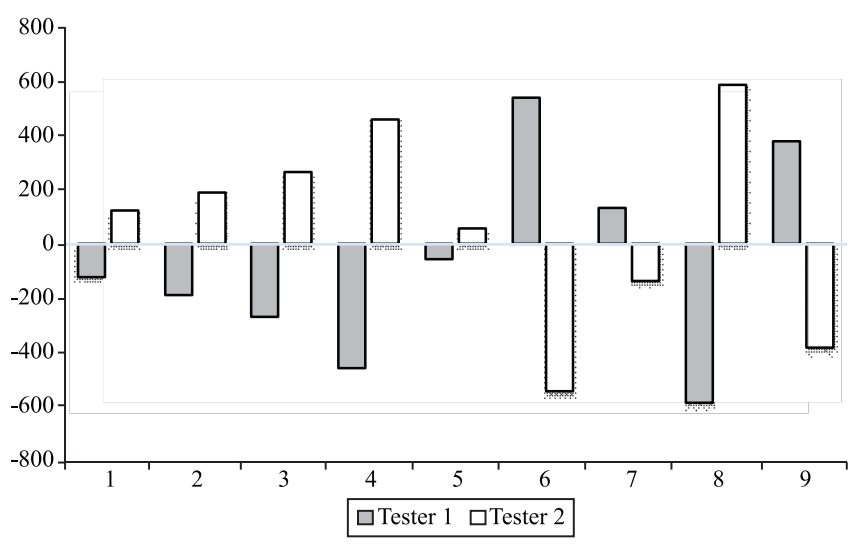

Figure 1. Estimates (contribution in $\mathrm{kg} \mathrm{ha}^{-1}$ ) of the combining general ability of the two testers used to classify the genetic merit of corn (Zea mays) hybrids in each of the nine evaluated environments in the states of Paraná and Mato Grosso do Sul, Brazil. In the state of Paraná: 1, Toledo; 2, Palotina; 3, Assis Chateaubriand; 4, Campo Mourão; 5, Sertanópolis; and 6, São Jorge do Ivaí. In the state of Mato Grosso do Sul: 7, Caarapó; 8, Itaporã; and 9, Douradina.
GxE interaction. This interaction indicates that there is a variation in the performance of the genotypes in the environments they were assessed.

According to the analysis of variance and the decomposition of the sum of squares of the interaction, the first two principal components (IPCA 1 and IPCA 2) were significant by Gollob's F-test (Table 6). IPCA 1 explained $46.17 \%$ of the variation in the sum of squares $(\mathrm{GxE})$ with 72 degrees of freedom, whereas IPCA 2 explained $15.96 \%$ of the variation in the sum of squares $(\mathrm{GxE})$ with 70 degrees of freedom. As the two principal components explained the majority of the total variation of the interaction, they were sufficient to assess the stability and adaptability of the inbred lines, hybrids and testers, as well as the effect of the interaction using the AMMI genotype plus genotypeby-environment (GGE) biplot, as described by Duarte \& Vencovsky (1999) and Yan \& Tinker (2006).

The first "average vs stability" GGE biplot for AMMI (Figure 2) details the mean grain yield of each site and the mean performance of each genotype for each environment, providing important information regarding the profile of the environments (Yan, 2011; Oyekunle et al., 2017). Environment 4 induced the lowest mean yield of $7,183 \mathrm{~kg} \mathrm{ha}^{-1}$ of the genotypes, being considered the least recommended when aiming high grain yields. However, studies involving

Table 6. Summary of the joint analysis of variance of the grain yield ( $\left.\mathrm{kg} \mathrm{ha}^{-1}\right)$ of 66 corn (Zea mays) genotypes evaluated in nine environments ${ }^{(1)}$ in the second crop season, in the states of Paraná and Mato Grosso do Sul, Brazil.

\begin{tabular}{|c|c|c|c|c|}
\hline Source of variation ${ }^{(2)}$ & Degree of freedom & Sum of squares & Middle square & F-test \\
\hline Genotypes & 65 & 155.2300 & 2.3882 & $1.5202 * *$ \\
\hline Environment & 8 & 336.5845 & 42.0731 & $26.7824 * *$ \\
\hline Interaction & 520 & 816.8788 & 1.5709 & $1.4252 * *$ \\
\hline IPCA 1 & 72 & 377.1722 & 5.2385 & $4.7526^{* *}$ \\
\hline IPCA 2 & 70 & 129.4283 & 1.8490 & $1.6775^{* *}$ \\
\hline IPCA 3 & 68 & 88.5508 & 1.3022 & 1.1814 \\
\hline IPCA 4 & 66 & 71.5019 & 1.0834 & 0.9829 \\
\hline IPCA 5 & 64 & 56.0382 & 0.8756 & 0.7944 \\
\hline IPCA 6 & 62 & 41.0068 & 0.6614 & 0.6000 \\
\hline IPCA 7 & 60 & 29.0128 & 0.4835 & 0.4387 \\
\hline IPCA 8 & 58 & 24.1678 & 0.4167 & 0.3780 \\
\hline Mean error & 750 & 826.6813 & 1.1022 & \\
\hline Average $\left(\mathrm{kg} \mathrm{ha}^{-1}\right)$ & 8,650 & & & \\
\hline CV (\%) & 14.1 & & & \\
\hline
\end{tabular}

(1)In the state of Paraná: 1, Toledo; 2, Palotina; 3, Assis Chateaubriand; 4, Campo Mourão; 5, Sertanópolis; and 6, São Jorge do Ivaí. In the state of Mato Grosso do Sul: 7, Caarapó; 8, Itaporã; and 9, Douradina. ${ }^{(2)}$ IPCA, principal component. **Significant by Gollob's F-test, at 1\% probability. The mean error originates from the individual analyses of variance, i.e., from the weighted mean of the mean square errors of the crossings with five testers, reduced to the level of averages. 
environments with this characteristic are still important to determine the stability of hybrids with high yield potential even in unfavorable environments (Figure 2). In this context, hybrids HS102, HS212, HS223, HS232, and HS233 can be highlighted (Tables 3 and 4). Environments 2 and 6 provided conditions for the genotypes to reach the highest mean yields of 9.618 and 9,599 $\mathrm{kg} \mathrm{ha}^{-1}$, respectively (Figure 2).

Environment 6 resulted in a high mean yield and in low scores on the IPCA 1 axis, showing that it is a highly favorable environment, in which most of the evaluated hybrids had a good performance, and that it can be considered a key environment in the study of the adaptability of genotypes to be cultivated in the second crop season. As environment 6 was plotted close to the horizontal line in the AMMI biplot, it was decisive in the expression of genetic variance, with a low influence of environmental conditions on hybrid performance, so that the visualized phenotype is attributed mainly to genetic effects. This environment is also the most suitable for selecting promising genotypes and determining adaptability and stability estimates (Vencovsky \& Barriga, 1992; Ramalho et al., 2012).

Environment 5 presented a high IPCA 1 value and a relatively lower mean grain yield of $8,058 \mathrm{~kg} \mathrm{ha}^{-1}$, being important to evaluate the performance of genotypes in more unfavorable environments. Contrarily, environment 2 showed a high IPCA 1 value but also a high mean yield of $9,618 \mathrm{~kg} \mathrm{ha}^{-1}$, making it a favorable environment to assess the adaptability of hybrids (Figueiredo et al., 2015); however, in the present study, none of the hybrids presented specific adaptability to this environment.

Among the topcross hybrids that responded with higher grain yield values in the evaluated

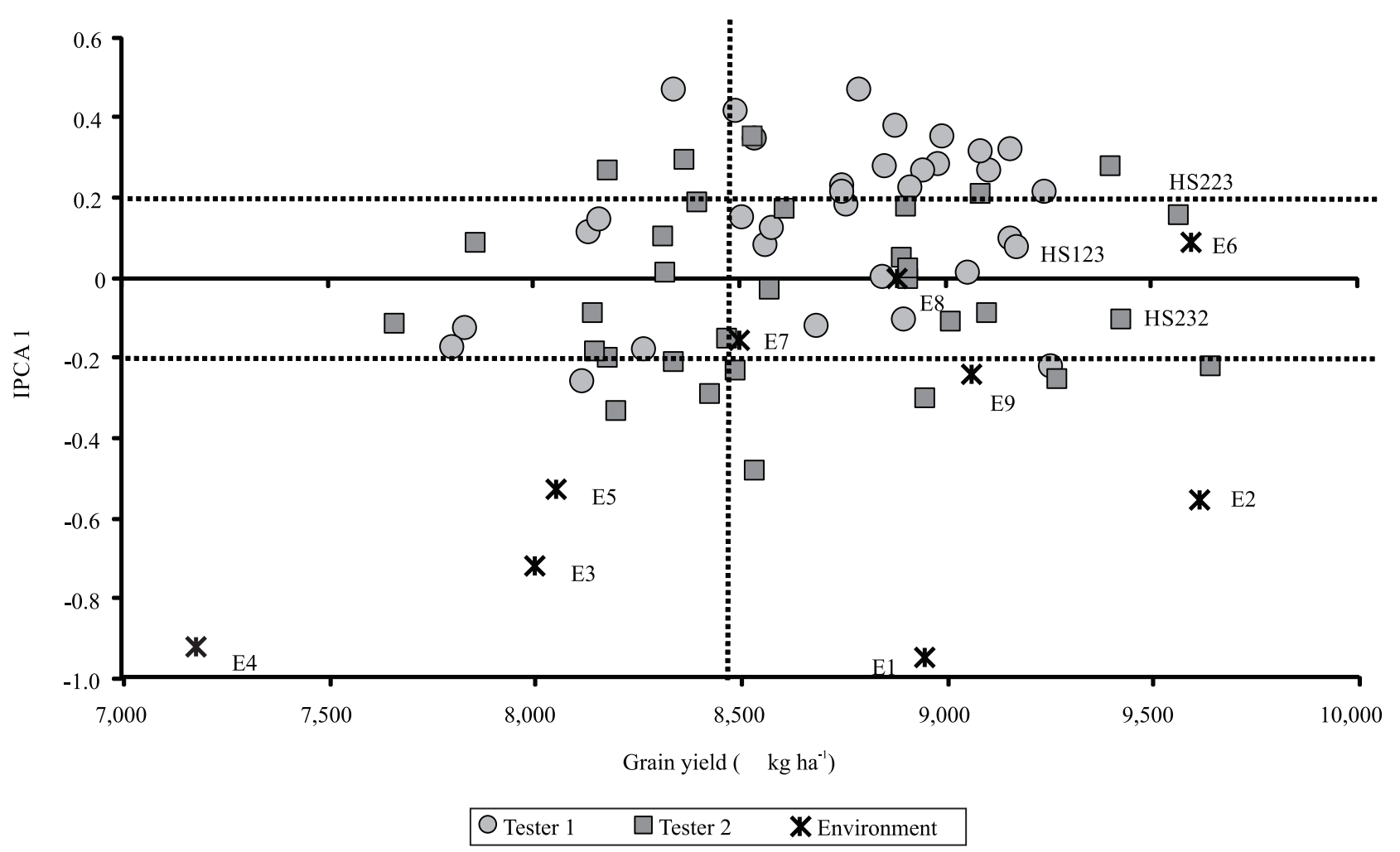

Figure 2. "Average vs stability" genotype plus genotype-by-environment (GGE) biplot for the first additive main effects and multiplicative interaction (AMMI 1) regarding the first principal component (IPCA 1) and the average grain yield of the hybrids and the nine environments in the states of Paraná and Mato Grosso do Sul, Brazil, in axes y and x, respectively. In the state of Paraná: E1, Toledo; E2, Palotina; E3, Assis Chateaubriand; E4, Campo Mourão; E5, Sertanópolis; and E6, São Jorge do Ivaí. In the state of Mato Grosso do Sul: E7, Caarapó; E8, Itaporã; and E9, Douradina. The vertical strip indicates the general average of the genotypes. 
environments, HS212, HS221, HS223, and HS232 stood out (Table 4). Moreover, it is possible to state that HS212 and HS232 were the most stable considering the set of environments.

Similarly, inbred lines 12, 21, 23, and 32 are recommended for use in hybrid combinations to be cultivated in the second crop season, which is attributed to their good adaptability and stability and high grain yield in the crosses they participated in the studied environments. These results indicate that the inbred lines of the selected topcross hybrids should be advanced in the breeding program for further evaluation of hybrid combinations in different sites.

The AMMI 2 model (IPCA 2 vs IPCA 1) showed the high stability of hybrids HS114, HS118, HS119, HS207, HS132, HS134, HS211, HS217, HS219, HS231, and HS233, which were plotted close to the center of the graph (Figure 3), representing a low GxE interaction, as described by Roozeboom et al. (2008) when evaluating several genotypes in contrasting environments. The HS123, HS223, and HS232 hybrids are the most recommended for secondcrop environments since they stood out among the genotypes, with an yield $\left(8,650 \mathrm{~kg} \mathrm{ha}^{-1}\right)$ above the general mean of the experiments and high estimates of stability and adaptability (Figure 3 )

Environment 5 also revealed that hybrids HS125, HS102, and HS222 had greater adaptability, while HS202 and HS230 were the best adapted in environment 6. Hybrids HS127, HS133, HS205, and HS218 were the least stable because they are the most distant from both axes (Figure 3).

In general, the hybrids with tester 1 turned out to be less stable and more adapted to environments similar to environments 7,8 , and 9. Considering environments $1,2,3,4$, and 6 , the hybrids with tester 2 presented, in general, greater adaptability (Figure 4). Therefore, both testers were complementary to discriminate the

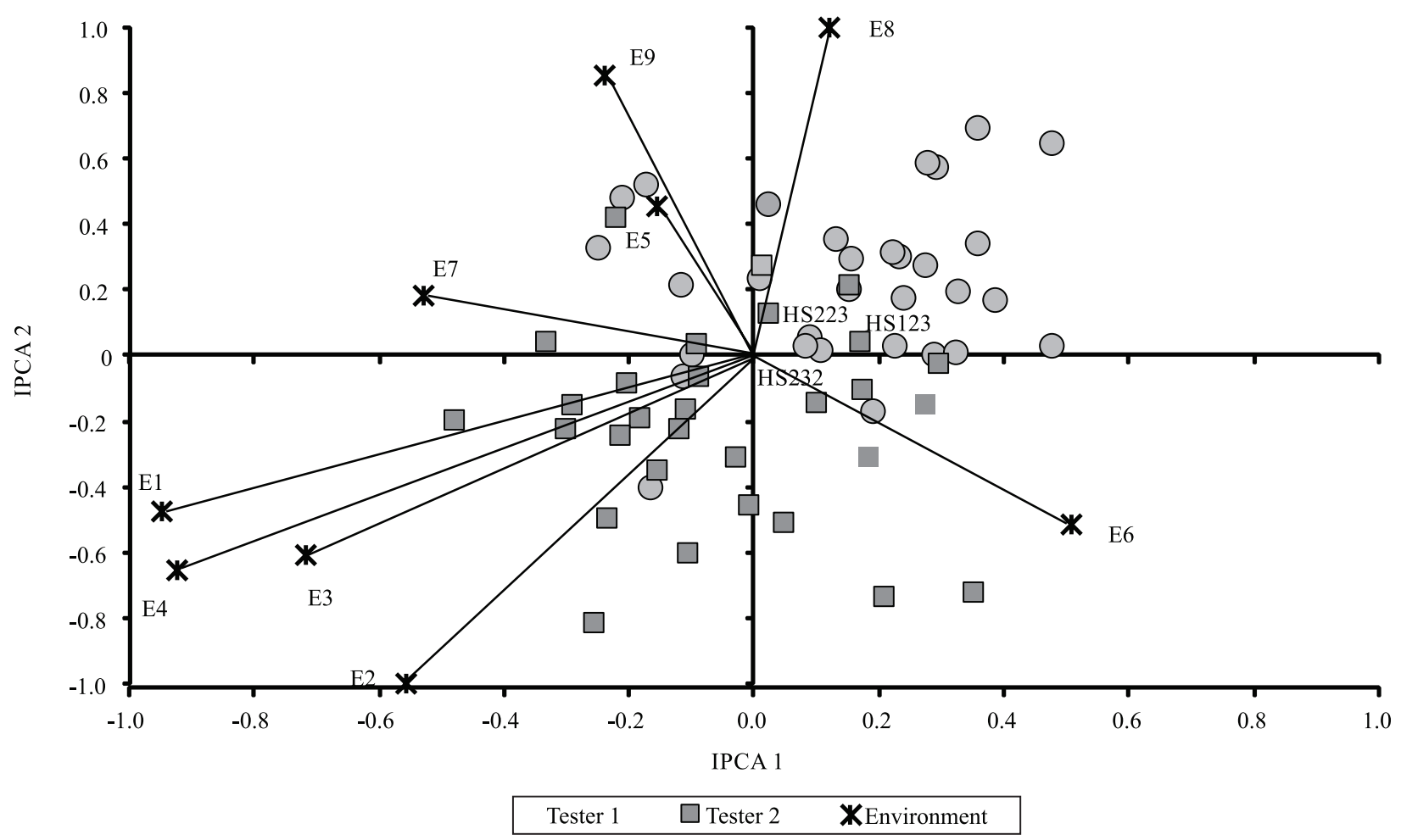

Figure 3. Genotype plus genotype-by-environment (GGE) biplot for the second additive main effects and multiplicative interaction (AMMI 2) regarding the first principal component (IPCA 1) and the second principal component (IPCA 2), in axes $\mathrm{x}$ and $\mathrm{y}$, respectively, for corn (Zea mays) hybrids evaluated in nine environments in the states of Paraná and Mato Grosso do Sul, Brazil. In the state of Paraná: E1, Toledo; E2, Palotina; E3, Assis Chateaubriand; E4, Campo Mourão; E5, Sertanópolis; and E6, São Jorge do Ivaí. In the state of Mato Grosso do Sul: E7, Caarapó; E8, Itaporã; and E9, Douradina. 


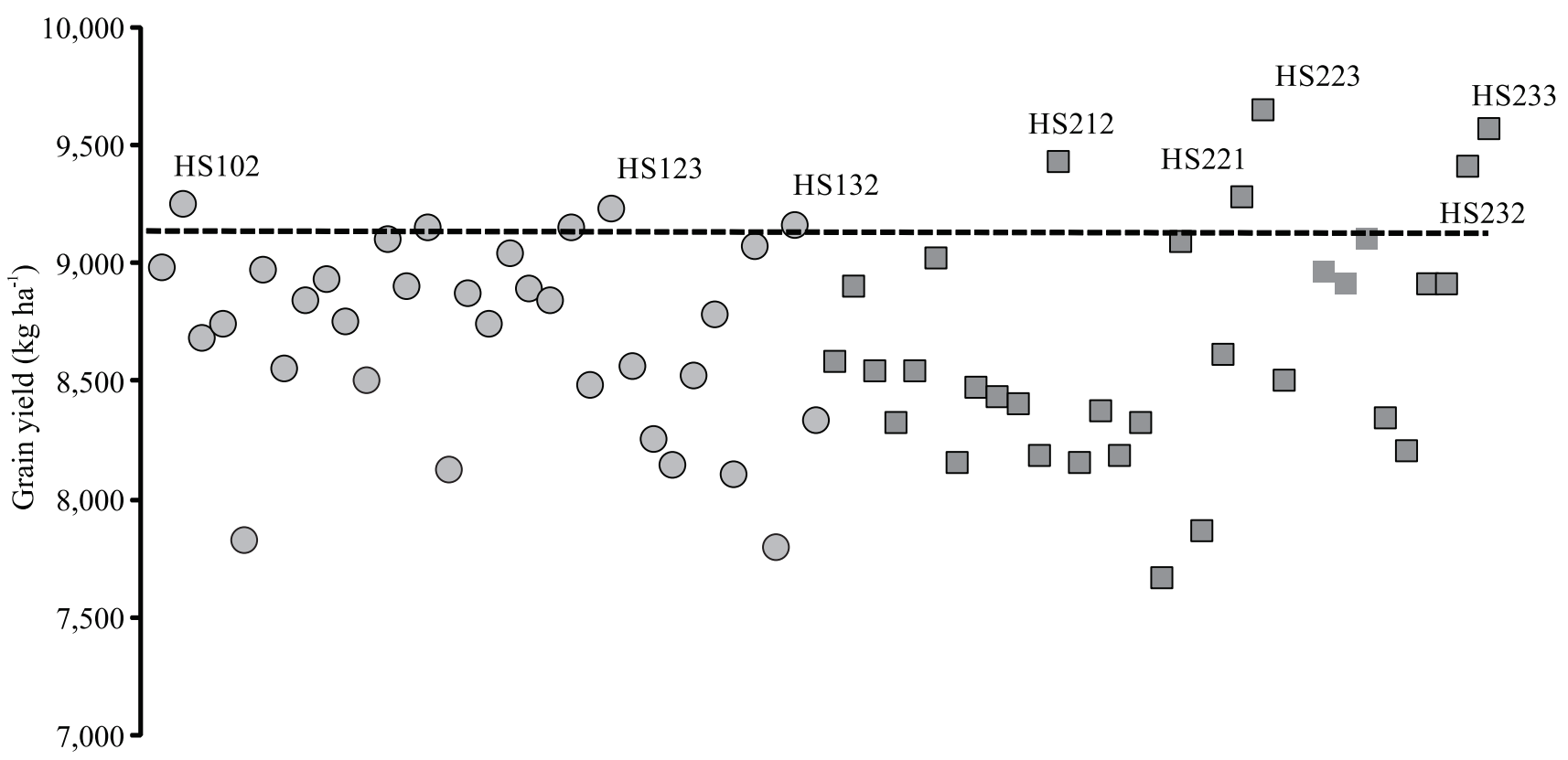

O Tester $1 \quad \square$ Tester 2

Figure 4. Dispersion of the average grain yields of corn (Zea mays) topcross hybrids with two testers in nine environments in the states of Paraná and Mato Grosso do Sul, Brazil. In the state of Paraná: 1, Toledo; 2, Palotina; 3, Assis Chateaubriand; 4, Campo Mourão; 5, Sertanópolis; and 6, São Jorge do Ivaí. In the state of Mato Grosso do Sul: 7, Caarapó; 8, Itaporã; and 9, Douradina. The dashed line points out the average of the treatments. The line shows the best hybrids grouped by the Scott-Knott test, at $5 \%$ probability.

inbred lines in the evaluated environments, suggesting the need of using more than one tester (Figueiredo et al., 2018; Rosa et al., 2020).

These results reinforce the importance of the choice of the tester not only to discriminate inbred lines, but also to aid in the selection of superior hybrids for each environment of interest, highlighting how the GxE interaction can interfere in decision-making (Yan, 2011; Mohamed, 2013).

\section{Conclusions}

1. Tester 2 is the most adapted to the environments of the second corn (Zea mays) crop season and efficiently discriminates the variability among inbred lines.

2. Inbred lines 12, 21, 23, and 32 are recommended for obtaining hybrids to be cultivated in the second crop season due to their good adaptability and stability and high yield in the crosses in which they participated.

3. Hybrids HS123, HS223, and HS232 present the best performance and are the most recommended for second-crop environments.

\section{References}

ANDREA, M.C. da S.; BOOTE, K.J.; SENTELHAS, P.C.; ROMANELLI, T.L. Variability and limitations of maize production in Brazil: potential yield, water-limited yield and yield gaps. Agricultural Systems, v.165, p.264-273, 2018. DOI: https://doi.org/10.1016/j.agsy.2018.07.004.

BOLSON, E.; SCAPIM, C.A.; CLOVIS, L.R.; AMARAL JUNIOR, A.T. do; FREITAS, I.L. de J. Capacidade combinatória de linhagens de milho avaliada por meio de testadores adaptados à safrinha. Revista Ceres, v.63, p.492-501, 2016. DOI: https://doi.org/10.1590/0034-737X201663040009.

CLOVIS, L.R.; SCAPIM, C.A.; PINTO, R.J.B.; BOLSON, E.; SENHORINHO, H.J.C. Avaliação de linhagens $\mathrm{S}_{3}$ de milho por meio de testadores adaptados à safrinha. Revista Caatinga, v.28, p.109-120, 2015.

COSTA, E.F.N.; SOUZA, J.C. de; LIMA, J.L.; CARDOSO, G.A. Interação entre genótipos e ambientes em diferentes tipos de híbridos de milho. Pesquisa Agropecuária Brasileira, v.45, p1433-1440, 2010. DOI: https://doi.org/10.1590/S0100204X2010001200014.

CRUZ, C.D. Genes: a software package for analysis in experimental statistics and quantitative genetics. Acta 
Scientiarum. Agronomy, v.35, p.271-276, 2013. DOI: https://doi.org/10.4025/actasciagron.v35i3.21251.

DAS, A.K.; MUTHUSAMY, V.; ZUNJARE, R.U.; CHAUHAN, H.S.; SHARMA, P.K.; BHAT, J.S.; GULERIAC, S.K.; SAHA, S.; HOSSAIN, F. Genetic variability-, genotype $\times$ environment interactions- and combining ability-analyses of kernel tocopherols among maize genotypes possessing novel allele of $\gamma$-tocopherol methyl transferase (ZmVTE4). Journal of Cereal Science, v.86, p.1-8, 2019. DOI: https://doi.org/10.1016/j.jcs.2018.12.018.

DI MATTEO, J.A.; FERREYRA, J.M.; CERRUDO, A.A.; ECHARTE, L.; ANDRADE, F.H. Yield potential and yield stability of Argentine maize hybrids over 45 years of breeding. Field Crops Research, v.197, p.107-116, 2016. DOI: https://doi.org/10.1016/j.fcr.2016.07.023.

DORIGATTI, G. Conab eleva estimativa da segunda safra de milho para 75,9 milhões de toneladas. 2020. Available at: $<$ https://www.noticiasagricolas.com.br/noticias/milho/259140conab-eleva-estimativa-da-segunda-safra-de-milho-para-759milhoes-de-toneladas.html\#.XvXrTG1Kjak>. Accessed on: Oct. 212020.

DUARTE, J.B.; VENCOVSKY, R. Interação genótipos $\mathrm{x}$ ambientes: uma introdução à análise "AMMI". Ribeirão Preto: Sociedade Brasileira de Genética, 1999. 60p.

FARIA, S.V.; LUZ, L.S.; RODRIGUES, M.C.; CARNEIRO, J.E. de S.; CARNEIRO, P.C.S.; DELIMA, R.O. Adaptability and stability in commercial maize hybrids in the southeast of the State of Minas Gerais, Brazil. Revista Ciência Agronômica, v.48, p.347357, 2017. DOI: https://doi.org/10.5935/1806-6690.20170040.

FIGUEIREDO, A.G. de; VON PINHO, R.G.; SILVA, H.D.; BALESTRE, M. Application of mixed models for evaluating stability and adaptability of maize using unbalanced data. Euphytica, v.202, p.393-409, 2015. DOI: https://doi.org/10.1007/ s10681-014-1301-3.

FIGUEIREDO, A.S.T.; PINTO, R.J.B.; SCAPIM, C.A.; RIZZARDI, D.A.; CONTRERAS-SOTO, R.I.; MATSUZAKI, R.A.; JOBIM, C.C.; FARIA, M.V. Topcrosses in the selection of testers and inbred lines $\mathrm{S}_{3}$ for the yield and bromatological quality of silage maize. Maydica, v.63, p.1-14, 2018.

FORNASIERI FILHO, D. Manual da cultura do milho. FUNEP, 2007. 574p.

GABRIEL, A; FARIA, M.V.; BATTISTELLI, G.M; ROSS, E.S; SILVA, C.A da; MARCK, D.F. de; GAVA, E. Desempenho agronômico e estabilidade de topcrosses de milho avaliados em Minas Gerais e Paraná. Revista Brasileira de Milho e Sorgo, v.17, p.303-316, 2018. DOI: https://doi.org/10.18512/1980-6477/ rbms.v17n2p303-316.

GAUCH JR., H.G. A simple protocol for AMMI analysis of yield trials. Crop Science, v.53, p.1860-1869, 2013. DOI: https://doi.org/10.2135/cropsci2013.04.0241.

GERALDI, I.O.; MIRANDA FILHO, J.B. de. Adapted models for the analysis of combining ability of varieties in partial diallel crosses. Revista Brasileira de Genética, v.11, p.419-430, 1988.

INMET. Instituto Nacional de Meteorologia. Normais Climatológicas (1961/2020). Brasília, 2020. Available at: $<$ https:// www.portal.inmet.gov.br>. Accessed on: Oct. 212020.
MOHAMED, N.E.M. Genotype by environment interactions for grain yield in bread wheat (Triticum aestivum L.). Journal of Plant Breeding and Crop Science, v.5, p.150-157, 2013. DOI: https://doi.org/10.5897/JPBCS2013.0390.

OLIBONI, R.; FARIA, M.V.; NEUMANN, M.; RESENDE, J.T.V.; BATTISTELli, G.M.; TEGONI, R.G.; OLIBONI, D.F. Análise dialélica na avaliação do potencial de híbridos de milho para a geração de populações-base para obtenção de linhagens. Semina: Ciências Agrárias, v.34, p.7-18, 2013. DOI: https://doi.org/10.5433/1679-0359.2013v34n1p7.

OLIVEIRA, T.R.A. de; CARVALHO, H.W.L. de; COSTA, E.F.N.; CARVALHO FILHO, J.L.S. de. Correlation among adaptability and stability assessment models in maize cultivars. Australian Journal of Crop Science, v.11, p.516-521, 2017. DOI: https://doi.org/10.21475/ajcs.17.11.05.p304.

OYEKUNLE, M.; HARUNA, A.; BADU-APRAKU, B.; USMAN, I.S.; MANI, H.; ADO, S.G.; OLAOYE, G.; OBENGANTWI, K.; ABDULMALIK, R.O.; AHMED, H.O. Assessment of early-maturing maize hybrids and testing sites using GGE biplot analysis. Crop Science, v.57, p.2942-2950, 2017. DOI: https://doi.org/10.2135/cropsci2016.12.1014.

PFANN, A.Z.; FARIA, M.V.; ANDRADE, A.A. de; NASCIMENTO, I.R. do; FARIA, C.M.D.R.; BRINGHENTTI, R.M. Capacidade combinatória entre híbridos simples de milho em dialelo circulante. Ciência Rural, v.39, p.635-641, 2009. DOI: https://doi.org/10.1590/S0103-84782009000300002.

POSSATTO JUNIOR, O.; FARIA, M.V.; BATTISTELLI, G.M.; ROSSI, E.S.; MARCK, D.F. de; SILVA, C.A. da; GABRIEL, A.; GRALAK, E. Avaliação de linhagens $\mathrm{S}_{2}$ de milho em topcrosses com linhagem-elite testadora. Revista Brasileira de Milho e Sorgo, v.16, p.297-309, 2017. DOI: https://doi.org/10.18512/19806477/rbms.v16n2p297-309.

R CORE TEAM. R: a language and environment for statistical computing. Vienna: R Foundation for Statistical Computing, 2015.

RAMALHO, M.A.P.; ABREU, A. de F.B.; SANTOS, J.B. dos; NUNES, J.A.R. Aplicações da genética quantitativa no melhoramento de plantas autógamas. Lavras: UFLA, 2012. $522 \mathrm{p}$.

ROOZEBOOM, K.L.; SCHAPAUGH, W.T.; TUINSTRA, M.R.; VANDERLIP, R.L.; MILLIKEN, G.A. Testing wheat in variable environments: genotype, environment, interaction effects, and grouping test locations. Crop Science, v.48, p.317-330, 2008. DOI: https://doi.org/10.2135/cropsci2007.04.0209.

ROSA, J.C.; FARIA, M.V.; ZALUSKI, W.L.; GAVA, E.; ANDREOLI, P.H.W.; SAGAE, V.S. Forage potential of $\mathrm{S}_{3}$ corn progenies in topcrosses and selection of testers of different genetic bases. Pesquisa Agropecuária Brasileira, v.55, e01283, 2020. DOI: https://doi.org/10.1590/S1678-3921.pab2020.v55.01283.

SCHMILDT, E.R.; CRUZ, C.D. Análise da adaptabilidade e estabilidade do milho pelos métodos de Eberhart e Russell e de Annicchiarico. Revista Ceres, v.52, p.45-58, 2005.

SILVA, C.A. da; FARIA, M.V.; ROSSI, E.S.; POSSATTO JUNIOR, O.; BATTISTELlI, G.M.; GABRIEL, A.; MARCK, D.F. de. Performance and stability of maize topcross hybrids from 
partly inbred lines. Semina: Ciências Agrárias, v.38, p.28992908, 2017.

VAN EEUWIJK, F.A.; BUSTOS-KORTS, D.V.; MALOSETTI, M. What should students in plant breeding know about the statistical aspects of genotype $\mathrm{x}$ environment interactions? Crop Science, v.56, p.2119-2140, 2016. DOI: https://doi.org/10.2135/ cropsci2015.06.0375.

VENCOVSKY, R.; BARRIGA, P. Genética biométrica no fitomelhoramento. Ribeirão Preto: Sociedade Brasileira de Genética, 1992. 486p.
YAN, W. GGE biplot vs. AMMI graphs for genotype-byenvironment data analysis. Journal of the Indian Society of Agricultural Statistics, v.65, p.181-193, 2011.

YAN, W:; TINKER, N.A. Biplot analysis of multi-environment trial data: principles and applications. Canadian Journal of Plant Science, v.86, p.623-645, 2006. DOI: https://doi.org/10.4141/ P05-169.

ZOBEL, R.W.; WRIGHT, M.J.; GAUCH JR., H.G. Statistical analysis of a yield trial. Agronomy Journal, v.80, p.388-393, 1988. DOI: https://doi.org/10.2134/agronj1988.000219620080000 30002x. 